(C) Ткачук Г.С., 2020 p.

https://orcid.org/0000-0003-3502-0557

https://doi.org/10.34142/23128046.2020.48.12

Г. С. Ткачук

\title{
КВАЛІМЕТРИЧНЕ ДОСЛІДЖЕННЯ ЕЛЕМЕНТІВ ПРОЦЕСУ УЧІННЯ НА ПРИКЛАДІ ВИВЧЕННЯ ХІМІЧНИХ ДИСЦИПЛІН
}

У прачі (Tkachuk, 2019) нами було розкрите формування технології учіння в прочесі вивчення хімічних дисииплін у класичних університетах як головної складової навчального прочесу. При иььому розглянуті можливості вирімення практичної реалізачії всіх восьми запропонованих елементів технології учіння. Однак, в цій прачі не вистачає аналізу впливу вхідних $i$ вихідних параметрів елементів технології учіння. Крім того, кваліметрію результатів учіння потрібно розглядати як певний елемент технології учіння. Метою статті є виявлення функціональних зв'язків між вхідними $i$ вихідними параметрами прочесу учіння, виявлення на цій основі аналітичних співвідношень, що характеризують процес учіння, розгляд кваліметрії учіння не лише як засобу кількісної оцінки процесів якісного характеру, але як $i$ певний елемент технології учіння. У роботі застосовані теоретичні методи дослідження, експериментальні методи виконання вимірювань фізичних величин, математичне моделювання та комп'ютерна обробка дослідних даних. У праці виявлено, щз вихідні параметри досліджених $n$ 'яти елементів технології учіння мають не випадковий характер а підпорядковуються математичним законам. Гістограма розподілу підготовки до учіння описується законом рівномірного розподілу. Гістограма розподілу вихідного параметра сприймання має трапецеїдальний характер. Емпіричний закон розподілу вихідного параметра розуміння описується нормальним законом розподілу Гауса. Теоретичні закони вірогідності розподілу та закон розподілу густини вірогідності для запам'ятовування одержані як результат композиції закону розподілу Гауса та закону рівної вірогідності. Густина вірогідності розподілу кваліметричного оцінювання рівня забезпечення міџності знань визначається за законом Сімпсона $i \epsilon$ розподілом по рівнобедреному трикутнику. Нами було досліджено п'ять елементів технології учіння. Подальші дослідження визначатимуть вихідні параметри наступних трьох елементів технології учіння $i$ перевірку правдоподібності припущення, як узгоджуються емпіричні результати 3 гіпотезою про те, чи випадкова величина, яка розглядається, підпорядковується теоретичному закону розподілу. Важливим є питання, чи виявлена в емпіричних даних тенденція до залежності між двома 
випадковими є дійсно об'єктивною залежністю, або ж вона пояснюється випадковими причинами, що пов'язано з недостатнім обсягом досліджень.

Ключові слова: вища освіта, учіння, елементи, технології учіння, кваліметрія, вхідні і вихідні параметри технології учіння.

\section{Tkachuk H. S. Quality-control research of elements of the learning process by an example of studying chemical disciplines.}

Annotation. In paper (Tkachuk, 2019), we revealed the formation of learning technology in the process of studying chemical disciplines at classical universities as the main component of the educational process. The possibilities of solving the practical implementation of all eight proposed elements of the learning technology are considered. However, this work lacks an analysis of the impact of input and output parameters of the learning technology elements. In addition, the quality control of the learning outcomes should be considered as a definite part of the learning technology. The aim of the present article is to identify functional relationships between input and output parameters of the learning process, to reveal on this basis analytical relationships that characterize the learning process, to consider the learning quality control not only as a means of quantifying qualitative processes but also as a certain element of the learning technology. The paper uses theoretical research methods, experimental methods for measuring physical quantities, mathematical modeling and computer processing of experimental data. At the same time, scientific and educational-methodical editions of the author on chemical educational disciplines are used. The paper reveals that the output parameters of the studied five elements of the learning technology are not random and are subject to mathematical laws. A histogram of the distribution of preparation for learning is described by a uniform distribution. A histogram of the distribution of the output parameter of perception has a trapezoidal feature. An empirical distribution of the output parameter of understanding is described by a normal Gaussian distribution. The theoretical laws of probability distribution and the law of probability density distribution for memorization are obtained as a result of the composition of the Gaussian distribution and the uniform distribution. The probability density of the distribution of quality-control estimation of the level of ensuring the strength of knowledge is determined by the Simpson's law, which is an isosceles triangle distribution. The purpose of further research is to determine the output parameters of the next three elements of the learning technology and test the plausibility of the assumption, how the empirical results are consistent with the hypothesis of whether the considered random variable is subject to the theoretical distribution. Nonetheless, an important question is whether the tendency found in empirical data for a relationship between two random variables is really an objective relationship between them, or whether it is justified by random causes due to insufficient research expansion.

Keywords: higher education, learning, elements, learning technology, quality control, input and output parameters of the learning technology. 
Вступ. Свроінтеграція України в галузі освіти й науки визначає потреби розроблення та оптимізації методичної і організаційної системи навчального процесу в вишах. Оскільки невід'ємною складовою навчального процесу $\epsilon$ учіння, котре 3 запровадженням карантинних обмежень та фактично суцільних дистанційних технологій, стало ще більше переважати над процесом викладання, кваліметричне моніторингове оцінювання результатів учіння є важливим і актуальним (Tkachuk, 2013).

У праці (Tkachuk, 2019) нами було розкрите формування технології учіння в процесі вивчення хімічних дисциплін у класичних університетах як головної складової навчального процесу і розглянуті можливості вирішення практичної реалізації всіх восьми запропонованих елементів технології процесу учіння. Ось ці елементи: підготовка до учіння, сприймання, розуміння, запам'ятовування, забезпечення міцності знань, узагальнення, систематизація, досягнення розвинених умінь та навичок. Однак, в цій праці не вистачає аналізу впливу вхідних і вихідних параметрів елементів технології учіння.

Мета та завдання. Метою статті $є$ виявлення функціональних зв'язків між вхідними і вихідними параметрами процесу учіння, виявлення на цій основі аналітичних співвідношень, що характеризують процес учіння, розгляд кваліметрії учіння не лише як засобу кількісної оцінки процесів якісного характеру, але як і певний елемент технології учіння. Відповідно до зазначеної мети у статті поставлені такі завдання: оцінювання результатів учіння здійснювати в рамках реалізації цілком певного елемента технології учіння; за критерій оцінювання рівня технології учіння прийняти кваліметричну оцінка математичного сподівання успішності за результатами поточного моніторингу процесу учіння; встановити закони розподілу елементів технологічного процесу учіння (Romanuke, 2018).

Методи дослідження. У роботі застосовані теоретичні методи дослідження, педагогічний експеримент, експериментальні методи виконання вимірювань фізичних величин, методи математичної статистики, математичне моделювання та комп’ютерна обробка дослідних даних.

Результати. Такі елементи технології процесу учіння, як сприймання, розуміння, запам'ятовування, мають цілком певне значення у механізмі технології учіння. Будемо вважати, що всі окремі елементи технології процесу учіння не перебувають у функціональному або кореляційному зв'язку та мають однакові вагові коефіцієнти, як на це звернено увагу в праці 
(Skyba, 2009), моніторингове оцінювання якості кожного з окремих елементів технології учіння з наступним оцінюванням якості всієї технології учіння пов’язане зі значними методичними та математичними труднощами, що зумовлено різною фізичною природою цих елементів. В цьому полягає головна причина застосування методів кваліметрії (Tsyba, 2002) для вимірювання якісних величин i процесів кількісними методами. Для більшості елементів технології учіння пряме оцінювання навчальних досягнень не можливе.

Вирішити таку непросту проблему запропоновано в праці (Skyba, 2009), а саме: всім структурним елементам технології учіння встановлюють три рівні оцінок: незадовільний, коли цей елемент технології зовсім не виявляє властиві йому функції у механізмі формування технологї учіння, або коли він чисельно оцінюється незадовільною оцінкою; задовільний, коли він в основному в достатній мірі виявляє себе в механізмі формування певної складової технології учіння; i, достатній рівень. Чисельно названі рівні оцінювання навчальних досягнень студентів (здобувачів освіти) виражаються цифрами $0 ; 1 ; 2$.

Якщо таким чином зробити моніторингове оцінювання рівня навчальних досягнень в учінні за елементами його технологій, то це дозволить в цілому зробити кваліметричне оцінювання рівня процесу учіння. Слід мати на увазі, що реалізація кваліметричного підходу до процесу учіння вимагає запровадження цілої системи виявлення, збору та обробки інформації про хід процесу учіння та його результати. В цю систему мають входити контрольні заходи, починаючи 3 поточного опитування, робота 3 тестовими матеріалами і закінчуючи видами виконаних контрольних заходів. Кваліметрію слід розглядати не як ізольовану законсервовану систему, а як невід'ємну частину технології учіння, враховуючи зворотні зв'язки технології цих процесів із пошуком ефективних форм і методів впливу на якість навчального процесу. Можна вважати кваліметрію як діючу i невід'ємну частину технології процесу учіння.

Виявимо залежності між вхідними та вихідними параметрами технології. Вхідним параметром слід вважати елементи технології процесу учіння (Tkachuk, 2019). Наприклад, технологія забезпечення розуміння передбачає застосування цілком певних підпорядкованих дій: наочності, засобів візуалізації, зразків хімічних речовин та обладнання, демонстрації хімічного експерименту, молекулярного моделювання тощо. Вихідними ж параметрами $\epsilon$ результат застосування тієї чи іншої технології, що 
вимірюються навчальними досягненнями студентів в процесі учіння. Кваліметричною мірою цих досягнень є місце даної позиції в трибальній системі оцінок 0; 1; 2 рівня технологій процесу учіння. Ці результати дозволяють виявити характерну міру впливу вхідних параметрів на навчальні досягнення в учінні.

Будемо вважати певну величину $x$, що прийнята за вихідну в технології процесу учіння одномірною неперервною випадковою величиною. Сукупність можливих значень випадкової величини і вірогідності того, що вона прийме ці можливі значення, утворюють закон ii розподілу. Вичерпними вірогіднісними характеристиками випадкової величини є іiі закони розподілу (Livshits, 1963). С два види розподілу випадкових величин: інтегральний та диференціальний. Диференціальним законом розподілу $f(x)$, випадкової величини $x$ називають похідну від їі інтегрального закону розподілу. Потрібно врахувати можливості законів розподілу, що виявляються в процесі їх використання: області можливих значень величини $x$; густини вірогідності $\varphi(x)$ в середині цієї області, причому за межами області можливих значень, густина вірогідності дорівнює нулю, а густина вірогідності $\varphi(x) \in$ границя відношення вірогідності того, що величина $x$ має значення в інтервалі $(x, x+\Delta x)$ до величини інтервалу $\Delta x$, коли $\Delta x \rightarrow 0$ (Livshits, 1963). Слід мати на увазі, що $\int_{-\infty}^{+\infty} \varphi(x) d x=1$, а одиниця вимірювання густини ймовірності $\varphi(x) \epsilon$ оберненою величиною одиниці вимірювання величини $x$.

Такі властивості закону розподілу випадкової величини (в даному випадку кваліметричної оцінки технології процесу учіння) дозволяють використати закони іiі розподілу для моделювання. Воно може відбуватись спочатку на рівні створення графічних моделей технологічних процесів, спочатку у вигляді гістограм, або полігонів розподілу експериментальних даних, а потім уже доведених відпрацьованих i вигладжених кривих розподілу вихідних величин, які представляють як графічні моделі технологічних процесів. Наступним етапом $\epsilon$ створення математичних моделей технологічних процесів учіння шляхом апроксимації одержаних графічних залежностей законів розподілу аналітичними залежностями або їх елементами.

Розглянемо складові технологічного процесу учіння в послідовності, поданій в праці (Tkachuk, 2019). Кожній зі складових технології учіння присвоєний номер, що відповідає їі місцю в структурі технології в цілому з 136 
використанням по тексту посилань на ці номери. Причому зазначимо, що кожний із восьми елементів технології учіння представлений кількістю студентів, що змінювалась в межах від $N=250$ осіб, до $N=320$ осіб.

На рис. 1 за експериментальними даними побудована гістограма розподілу елемента технології учіння 1 - підготовка до учіння при $N=250$. Підготовка студентів-хіміків до процесу учіння полягає в актуалізації їхнього інтересу до учіння, забезпеченні позитивної мотивації шляхом демонстрації перспектив здобуття вищої освіти за обраним фахом хіміка, матеріальної стипендіальної підтримки, цікавим викладанням навчального матеріалу, що не важко реалізувати через великі обсяги лабораторного практикуму та практик на виробництві у навчальному плані підготовки хіміків (Tkachuk, 2019).

На рис. 1 позначено, що $n_{i}-$ кількість спостережень результатів моніторингу учіння; $n_{i}^{*}$ - кількість спостережень в $i$-му розряді масиву з $\mathrm{N}$ спостережень. Нами прийнята кількість розрядів $k$ спостережень. Слід звернути увагу на те, що $\sum_{i=1}^{N} n_{i}=\sum_{i=1}^{k} n_{i}^{*}=N$, a $k=10$

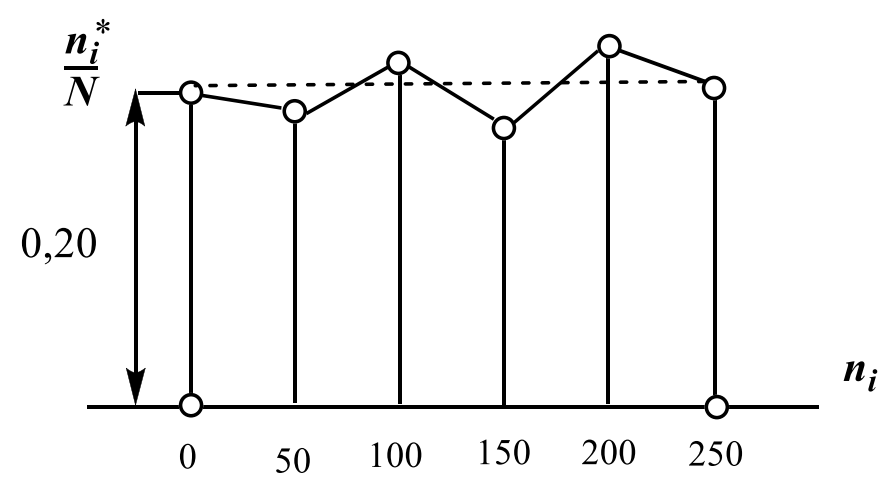

Рисунок 1 - Гістограма розподілу вихідного параметра елемента 1 технології учіння

Зовнішній вигляд гістограми розподілу підготовки до учіння дозволяє впевнитись, що він $\epsilon$ розподілом рівнів вірогідності або законом рівномірного розподілу (рис. 2). 


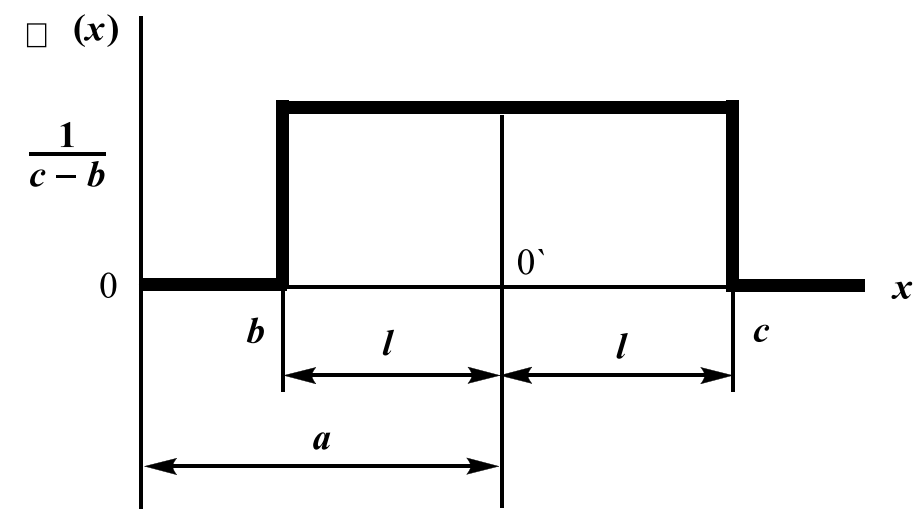

Рисунок 2 - Диференціальний закон рівномірного розподілу вихідного параметра елемента 1 технології учіння

Область можливих значень випадкової величини $x$, підпорядкований закону рівної вірогідності від $b$ до $c$ на рис. 2, або від $a-l$ до $a+l$. В цьому законі два параметри: $b$ і $c$, або від $a$ i $l$.

Отримали густину вірогідності (1) (Livshits, 1963), і функцію розподілу, або інтегральний закон рівномірного розподілу (2) (Vientsel, 1969):

$$
\begin{gathered}
\varphi(x)=\left\{\begin{array}{ccc}
0 & \text { при } & x<b, \\
\frac{1}{c-b} & \text { при } & b \leq x \leq c, \\
0 & \text { при } & x>c .
\end{array}\right. \\
F(x)=\left\{\begin{array}{ccc}
0 & \text { при } & x<b, \\
\frac{x-b}{c-b} & \text { при } & b \leq x \leq c, \\
1 & \text { при } & x>c .
\end{array}\right.
\end{gathered}
$$

Закон рівномірної густини вірогідності симетричний. В нашому випадку функція $x$ має верхню границю $x=2$, тому $c=2$, a $m_{1}(x)=1$. Вихідним фактором технології може бути сума двох або кількох взаємно незалежних випадкових величин $x, y, z \ldots$ (Vientsel, 1969). В цьому разі закон розподілу буде відноситися їхньої суми, тобто знаходження композиції закону розподілу. Ця операція має назву компонування закону розподілу i позначається символом * (Livshits, 1963). При цьому густина вірогідності суми двох незалежних випадкових величин визначається виразом (3):

$$
\varphi(x+y)=\varphi_{1}(x) * \cdot \varphi_{2}(y)=\int_{-\infty}^{+\infty} \varphi_{1}(x) \cdot \varphi_{2}(u-y) d x=\int_{-\infty}^{+\infty} \varphi_{2}(y) \cdot \varphi_{1}(u-y) d y,
$$

$$
\text { де } u=x+y \text {. }
$$


Можуть мати місце випадки, коли закон розподілу випадкової величини, що характеризує вихід параметра елемента 2 технології процесу учіння описується трапецеїдальним розподілом, геометрія якого подана на рис. 3.

Сприймання як другий елемент технології учіння - це процес відображення студентом предметів та явищ в цілому, в сукупності усіх інших якостей та властивостей при їхньому безпосередньому впливі на органи чуттів. Уважно студенти сприймають здебільшого лише цікаву чи дуже потрібну інформацію, що викликає в них спонтанний інтерес або коли вони перебувають у стані здивування та творчої активності (Tkachuk, 2019).

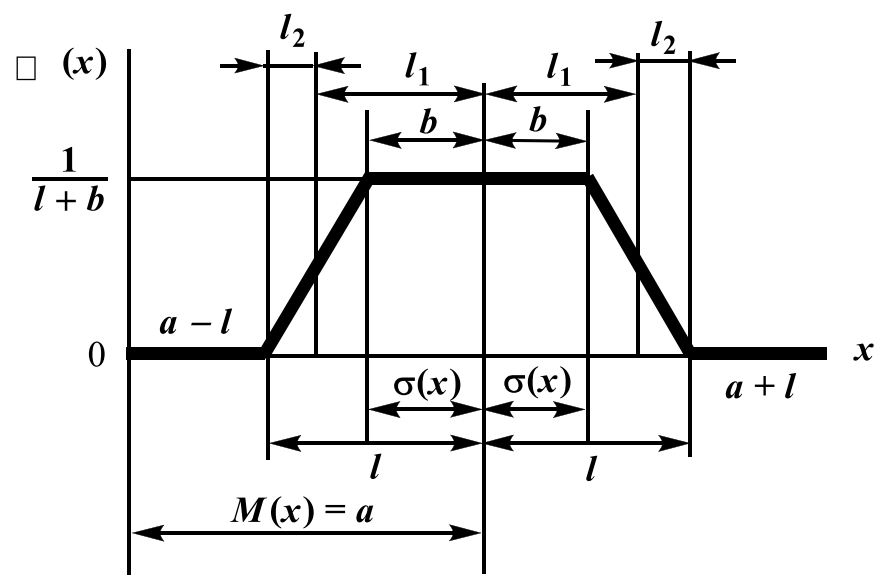

Рисунок 3 - Трапецеїдальний розподіл вихідного параметра елемента 2 технології учіння (Livshits, 1963)

Параметри закону, що зображені на рис. 3, три (Vientsel, 1969): $a=$ $M(x) ; \quad l=l_{1}+l_{2}-$ половина області можливих значень; $b=\left|l_{1}-l_{2}\right|-$ половина горизонтальної ділянки кривої розподілу.

Густина вірогідності трапецеїдального розподілу (Livshits, 1963) (4):

$$
\varphi(x)=\left\{\begin{array}{ccc}
0 & \text { при } & x<a-l, \\
\frac{x-a-1}{l^{2}-b^{2}} & \text { при } & a-l \leq x \leq a-b, \\
\frac{1}{l+b} & \text { при } & a-b \leq a+b, \\
\frac{a+l-x}{l^{2}-b^{2}} & \text { при } & a+b \leq x \leq a+l, \\
0 & \text { при } & x>a+l .
\end{array}\right.
$$

Математичне сподівання просто визначається за рис. 3 : $m_{2}(x)=l=1$. 
Третім елементом технології учіння є розуміння. Дуже важливою для передачі і розуміння інформації студентам-хімікам є мова хімічних символів, рівнянь хімічних реакцій, схем, графічних формул, результатів і аналітичних ефектів лабораторного практикуму і хімічного експерименту (Tkachuk, 2019).

Реалізація елемента 3 - розуміння технології учіння. Ї̈і представляє побудована за експериментальними даними гістограма розподілу елемента 3 - розуміння серед учасників учіння в кількості 250 осіб, що показано на рис. 4:

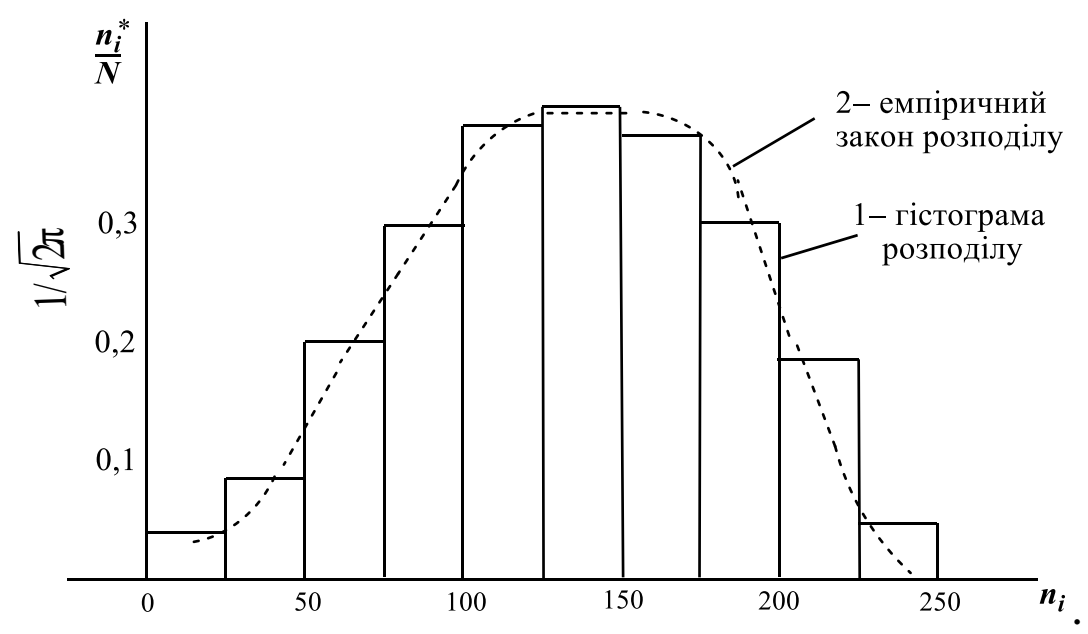

Рисунок 4 - Емпіричний закон розподілу вихідного параметра елемента 3 технології учіння

Теоретичний закон розподілу в цьому випадку є нормальний закон розподілу Гауса (Livshits, 1963). Густина розподілу вірогідності випадкової величини, що має гаусівський розподіл залежить від двох параметрів: математичного сподівання $a=m(x)$ і середнього квадратичного відхилення $\sigma=\frac{(x-a)^{2}}{2 \sigma^{2}}$ і визначається за рівнянням (5) (Vientsel, 1969):

$$
\varphi(x)=\frac{1}{\sigma \sqrt{2 \pi}} \cdot \exp , \quad x \in[-\infty ;+\infty]
$$

Математичне сподівання елемента 3 розуміння технології учіння дорівнює (Vientsel, 1969): $m_{3}(x)=0,9973 / 2 \approx 0,5$.

Крива 2 (рис. 4) зображає закон розподілу вихідного параметра елемента 3 - розуміння технології учіння.

Запам'ятовування $\epsilon$ четвертим елементом технології, котре також $\epsilon$ властивістю людини, без якої учіння як процес не можливе, воно полягає в закріпленні, зберіганні та наступному відтворенні студентом попереднього досвіду. Запам'ятовування відіграє визначну роль не лише при проведенні 
контрольних заходів для демонстрації ступеня опанування теоретичним матеріалом, але й потрібне при відтворенні та використані цього досвіду при вирішенні ситуативних задач 3 хімії, а також виробничих задач (Tkachuk, 2019). Розглянемо елемент 4 - запам'ятовування технології учіння на рис. 5.

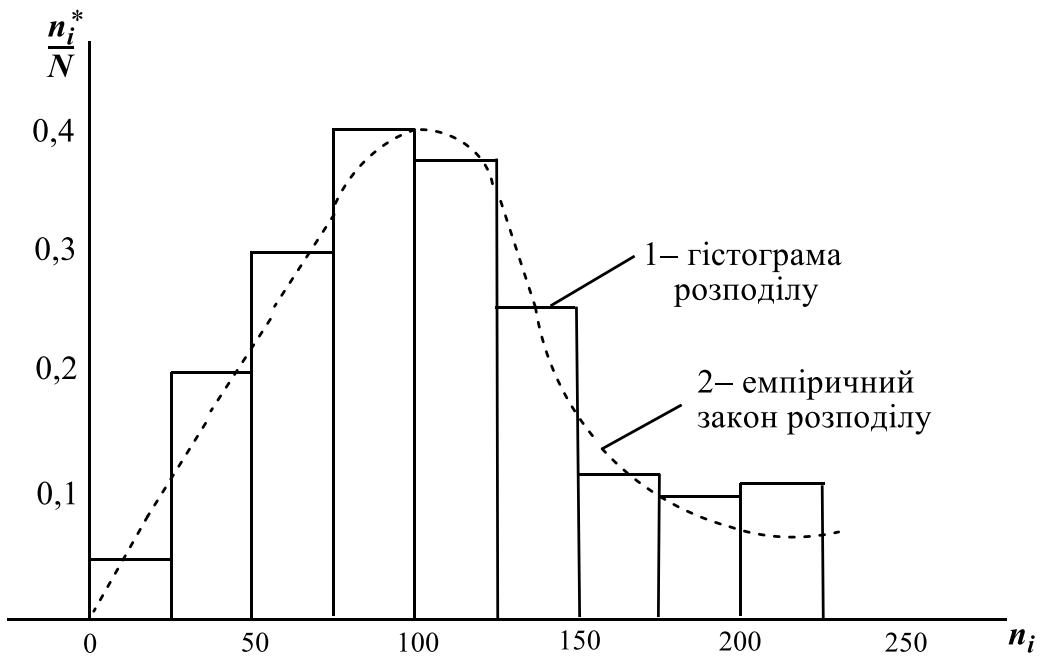

Рисунок 5 - Гістограма і емпіричний закон розподілу вихідного параметра елемента 4 технології учіння

На рисунку $N=250$, і ця гістограма за іiі зовнішніми ознаками $\epsilon$ композицією закону розподілу та закону рівної вірогідності, тобто суми випадкових величин $u=x+y$. Знайдемо аналітичну залежність для закону розподілу композиції, що характеризується виразом (6). Густина вірогідності випадкової величини визначається за законом Гауса і задається величиною:

$$
\varphi_{1}(x)=\frac{1}{\sigma_{0} \sqrt{2 \pi}} \cdot \exp \left(-\frac{x^{2}}{2 \sigma^{2}}\right), \quad \text { при } \quad-\infty \leq x \leq+\infty \text {. }
$$

Густину вірогідності величини у задаємо залежністю (7) (Livshits, 1963):

$$
\begin{array}{llll}
\varphi_{2}(y)=\frac{1}{2 \delta} & \text { при } & |y| \leq \delta, \\
\varphi_{2}(y)=0 & \text { при } & |y|>\delta .
\end{array}
$$

Із границь інтегрування по $x$ у рівнянні (6) виключається лише область значень, в якій $\varphi_{2}(y)=0$, оскільки $\varphi(x) \neq 0$ в межах від $-\infty$ до $+\infty$. Це наступні області: $-\infty<y-x<+\infty$, тобто $-\infty<x<u-\delta$. 3 цього одержуємо границі інтегрування по $x$ від $u-\delta$ до $u+\delta$. Причому врахуємо, що $\delta$ - половина величини заданого поля. Диференційний закон розподілу композицій закону розподілу Гауса і закону вірної вірогідності на основі викладеного вище 
описується залежністю (8) (Vientsel, 1969). Використавши функцію Лапласа (Vientsel, 1969), вираз (8) запишемо у вигляді (9) (Livshits, 1963):

$$
\begin{gathered}
\varphi_{1}(u)=\frac{1}{\delta} \cdot \frac{1}{\sigma_{c} \sqrt{2 \pi}} \cdot \int_{a-\delta}^{a+\delta} \exp \left(-\frac{x^{2}}{2 \sigma_{c}^{2}}\right) d x, \quad[-\infty<u<+\infty] . \\
\varphi(u)=\frac{1}{2 \delta}\left[\Phi\left(\frac{u+\delta}{\sigma_{0}}\right)-\Phi\left(\frac{u-\delta}{\sigma_{0}}\right)\right],
\end{gathered}
$$

Це $\epsilon$ аналітична залежність для закону розподілу вихідного параметра елемента технології 4 - запам'ятовування. Розрахуємо його при $\delta=0,5$ i $\sigma_{0}=$ 1 , враховуючи, що функція Лапласа $\epsilon$ непарною і $\Phi(-u)=-\Phi(u)$. Теоретичні закони вірогідності розподілу $\mathrm{F}(u)$ та закон розподілу густини вірогідності $\varphi(u)$ для вихідного параметра елемента 4 - запам'ятовування технології учіння одержані як результат композиції закону розподілу Гауса та закону рівної вірогідності зображені на рис. 6.

Забезпечення міцності знань $є$ п'ятим елементом технології учіння. Найбільш міцно в пам'яті студента утримується інформація, котра пов'язана 3 яскравим емоційним і образним фоном. Ефективними засобами зміцнення знань $\epsilon$ не лише яскравий емоційний виклад навчального матеріалу, але й уміле використання лабораторного практикуму 3 хімічних дисциплін (Tkachuk, 2019).

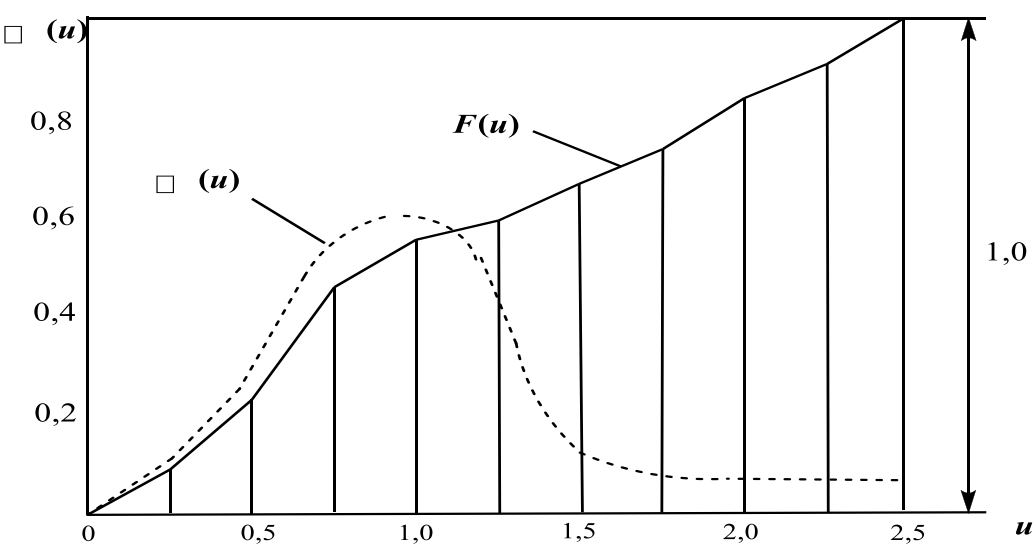

Рисунок 6 - Теоретичні закони вірогідності розподілу та закон розподілу густини вірогідності для вихідного параметра елемента 4 процесу учіння

При реалізації елемента технології 5 - забезпечення міцності знань іiі характеризує гістограма розподілу вихідного параметра елемента 5 технології, одержана емпіричним шляхом (рис. 7). 


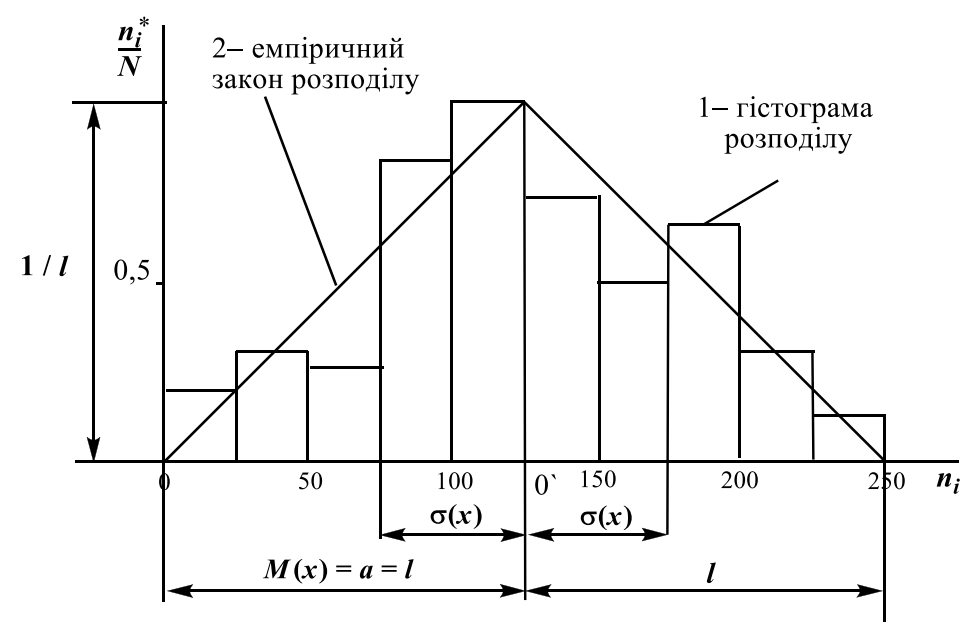

Рисунок 7 - Ілюстрація закону розподілу кваліметричного оцінювання рівня забезпечення міцності знань в процесі учіння

Закон розподілу кваліметричного оцінювання рівня забезпечення міцності знань в процесі учіння відповідає аналітичним співвідношенням (10). Густина вірогідності розподілу кваліметричного оцінювання рівня забезпечення міцності знань на підставі положень, що викладені вище, визначається за законом Сімпсона (Vientsel, 1969) - розподіл по рівнобедреному трикутнику.

Математичне сподівання обчислювалось за виразом : $m_{5}(x)=\mathrm{a}=l=1,0$.

$$
\varphi(x)=\left\{\begin{array}{ccc}
0 & \text { при } & x<a-l, \\
\frac{l+x-a}{l^{2}} & \text { при } & a-l \leq x<a, \\
\frac{l+x+a}{l^{2}} & \text { при } & a \leq x \leq a+l, \\
0 & \text { при } & x>a+l .
\end{array}\right.
$$

Обговорення. Нами було досліджено п'ять елементів технології учіння. Подальші дослідження визначатимуть вихідні параметри наступних трьох елементів технології учіння і перевірка правдоподібності припущення, як узгоджуються емпіричні результати з гіпотезою про те, чи випадкова величина, яка розглядається, підпорядковується теоретичному закону розподілу. Важливим $є$ питання, чи виявлена в емпіричних даних тенденція до залежності між двома випадковими є дійсно об'єктивною залежністю, або ж вона пояснюється випадковими причинами, що пов'язано з недостатнім обсягом досліджень.

\section{Висновки.}


1. Вихідні параметри досліджених п'яти елементів технології учіння мають не випадковий характер а підпорядковуються математичним законам.

2. Гістограма розподілу підготовки до учіння описується законом рівномірного розподілу.

3. Гістограма розподілу вихідного параметра сприймання має трапецеїдальний характер.

4. Емпіричний закон розподілу вихідного параметра розуміння описується нормальним законом розподілу Гауса.

5. Теоретичні закони вірогідності розподілу та закон розподілу густини вірогідності для запам'ятовування одержані як результат композиції закону розподілу Гауса та закону рівної вірогідності.

6. Густина вірогідності розподілу кваліметричного оцінювання рівня забезпечення міцності знань визначається за законом Сімпсона - розподіл по рівнобедреному трикутнику.

\section{ЛIТЕРАТУРА:}

Romanuke V. V. Decision making criteria hybridization for finding optimal decisions' subset regarding changes of the decision function // Journal of Uncertain Systems, 2018, vol. 12, no. 4 , pp. $279-291$.

Tkachuk A. The Discipline Problem of Students under Condition of Academic Mobility / A. Tkachuk, S. Karvan // Abstracts of International Conference "New Perspectives in Science Education", Florence, Italy, 14-15.03.2013. - http://www.pixelonline.net/npse2013/acceptedabstracts.php.

Вентцель Е. С. Теория вероятности / Е. С. Вентцель. - М. : Изд-во «Наука». Главная редакция физ-мат литературы. - 1969. - 575 с.

Лившиц Н. А., Вероятностный анализ систем автоматического управления / Н. А. Лифшиц, В. Н Пугачев. - М.: Советское радио, 1963. - 896 с.

Скиба М. Є. Моніторинг якості навчального процесу у вищому закладі освіти : монографія / М. Є. Скиба, С. Г. Костогриз, Г. В. Красильникова. - Хмельницький : ХHУ, 2009. $-219 \mathrm{c}$.

Ткачук Г. С. Учіння як базовий елемент технології навчального процесу. Теорія та методика навчання та виховання. 2019. № 47. - С. 133-147. DOI: 10.34142/23128046.2019.47.12.

Циба В. Т. Математичні основи соціологічних досліджень: кваліметричний підхід / В. Т. Циба. - Київ: МАУП, 2002. - 248 с.

\section{REFERENCES:}

Livshits N. A. \& Pugachev N. A. (1963). Vieroyatnostnyi analiz sistiem avtomaticheskogo upravlieniya [Probabilistic analysis of automatic control systems] Moskva, Sovietskoye radio.

Romanuke V. V. (2018). Decision making criteria hybridization for finding optimal decisions' subset regarding changes of the decision function. Journal of Uncertain Systems. vol. 12, no. 4 , pp. $279-291$. 
Skyba M. Ye., Kostohryz S. H. \& Krasylnykova H. V. (2009). Monitorynh yakosti navchalnoho protsesu u vyshchomu zakladi osvity [Monitoring the quality of the educational process in a higher education institution] Khmelnytskyi, KhNU.

Tkachuk A. \& Karvan S. (2013). The Discipline Problem of Students under Condition of Academic Mobility. International Conference "New Perspectives in Science Education", Florence, Italy. http://www.pixel-online.net/npse2013/acceptedabstracts.php.

Tkachuk H. S. (2019). Uchinnya yak bazovyi element tekhnolohii navchalnoho protsesu [Learning as a basic element of the technology of the educational process]. Teoriya ta metodyka navchannya ta vychovannya, 47, 133-147.

Tsyba V. T. (2002). Matematychni osnovy sotsiolohichnych doslidzhen: kvalimetrychnyi pidkhid [Mathematical foundations of sociological research: a qualimetric approach.] Kyiv, MAUP.

Vientsel Ye. S. (1969). Tieoriya vieroyatnosti [Probability theory] / Ye. S. Ventsel. Moskva, Nauka.

\begin{tabular}{|c|c|}
\hline Інформація про автора: & Information about the author: \\
\hline Ткачук Ганна Сергївна: & Tkachuk Hanna Sergiyivna: \\
\hline $\begin{array}{l}\text { ORCID: https://orcid.org/0000-0003-3502- } \\
\text { 0557, кандидат технічних наук, доцент } \\
\text { кафедри хімії та хімічної інженерії } \\
\text { Хмельницького } \\
\text { національного }\end{array}$ & $\begin{array}{l}\text { ORCID: https://orcid.org/0000-0003-3502- } \\
\text { 0557, Candidate of Technical Sciences, } \\
\text { Associate Professor of the Department of } \\
\text { Chemistry and Chemical Engineering at the }\end{array}$ \\
\hline $\begin{array}{l}\text { університету, } 29016, \quad \text { Україна, } \\
\text { Хмельницький, вул. Інститутська,11. }\end{array}$ & $\begin{array}{l}\text { Khmelnytskyi National University, } 29016 \text {, } \\
\text { Ukraine, Khmelnytskyi, Instytutska str., } 11 .\end{array}$ \\
\hline 190670anna363@ukr.net & 190670anna363@ukr.net \\
\hline
\end{tabular}

Цитуйте цю статтю як: Ткачук Г.С. Кваліметричне дослідження елементів процесу учіння на прикладі вивчення хімічних дисциплін. Теорія та методика навчання та виховання. 2020. № 48. С.132-145.

DOI: https://doi.org/10.34142/23128046.2020.48.12

Дата надходження статті до редакції:

Стаття прийнята до друку: 